\title{
PENERAPAN AKUNTANSI PADA KELOMPOK USAHA KECIL MENENGAH EKS PNPM DI KABUPATEN BINTAN
}

\section{APPLICATION OF ACCOUNTING IN SMALL AND MEDIUM BUSINESS GROUPS EX PNPM IN BINTAN DISTRICT}

\author{
Fatahurrazak1, Muhammad Idris. DM² \\ 1 Universitas Maritim Raja Ali Haji; Tanjungpinang \\ 2Universitas Maritim Raja Ali Haji; Tanjungpinang \\ faturajafatur@gmail.com
}

\begin{abstract}
ABSTRAK
Penelitian ini dilakukan untuk mengetahui apakah kelompok usaha yang menggunakan dana pinjaman untuk menjalankan dan mengembangkan usaha sudah menerapkan prinsip-prinsip akuntansi yang benar agar meraka dapat mengetahui perkembangan usaha, perkembangan asset dan perkembangan ekuitasnya. Populasi penelitian ini adalah seluruh kelompok yang mendapatkan pinjaman dari UPT yang tersebar di 10 kecamatan yang ada di kabupaten bintan, sampel penelitian diambil secara acak di setiap kecamatan. Hasil penelitian ini menyimpulkan kelompok usaha pada UKM di Kabupaten Bintan masih jauh dari kaidah penerapan akuntansi pada aktivitas usahanya. Dari hasil skor tertimbang sebesar 0.49 (Moderately low association (moderately weak association) pada skala Guttman diketahui bahwa penerapan akuntansi di UKM kabupaten Bintan masih kurang. Pemahaman atas persamaan dasar akuntansi hanya $45 \%$, melakukan pemisahan asset usaha dengan asset sendiri sebesar $43 \%$, membuat bukti transaksi dari setiap transaksi sebesar $59 \%$, mencatat seluruh transaksi yang terjadi sebesar $67 \%$, mencatat pengambilan pribadi (prive) sebesar $36 \%$, melakukan pembebanan asset tetap sebesar $28 \%$, melakukan peghitungan HPP perunit sebesar $64 \%$, menentukan penjualan paling minimal sebesar $45 \%$, dan menyusun laporan keuangan sebanyak $51 \%$.
\end{abstract}

Keywords : akuntansi untuk ukm, pelaku usaha kecil, penggunaan dana PNPM

\begin{abstract}
This research was conducted to find out whether business groups that use loan funds to run and develop businesses have applied the correct accounting principles so that they can find out business development, asset development and the development of their equity. The population of this study was that all groups that received loans from UPT were scattered in 10 sub-districts in Bintan Regency, the research samples were taken randomly in each sub-district. The results of this study conclude that business groups in SMEs in Bintan Regency are still far from the rules of applying accounting in their business activities. From the results of the weighted score of 0.49 (Moderately low association (moderately weak association) on the Guttman scale, it is known that the application of accounting in the Bintan district SMEs is still lacking. Understanding of the basic accounting equation is only $45 \%$, separating business assets from their own assets by $43 \%$, making transaction proof of each transaction amounted to $59 \%$, recording all transactions that occurred at $67 \%$, registering prive by $36 \%$, imposing fixed assets at $28 \%$, calculating perunit HPP by $64 \%$, determining the minimum sales of $45 \%$, and compile financial statements as much as $51 \%$.

Keywords: accounting for ukm, small businesses, use of PNPM funds
\end{abstract}




\section{PENDAHULUAN}

Masalah mendasar usaha kecil yang paling menonjol menyangkut menyediakan pembiayaan usaha alias modal usaha.Kebutuhan modal sangat terasa pada saat seseorang ingin memulai usaha baru. Alhasil, biasanya bila motivasinya kuat, seseorang akan tetap memulai usaha kecil tetapi dengan modal seadanya. Pada usaha yang sudah berjalan, modal tetap menjadi kendala lanjutan untuk berkembang.

Masalah yang menghadang usaha kecil menyangkut kemampuan akses pembiayaan, akses pasar dan pemasaran, tata kelola manajemen usaha kecil serta akses informasi.Kesulitan usaha kecil mengakses sumber-sumber modal karena keterbatasan informasi dan kemampuan menembus sumber modal tersebut.Padahal pilihan sumber modal sangat banyak dan beragam.

Unit Pengelola Kegiatan (UPK) PNPM Mandiri Perdesaan dan Perkotaan merupakan lembaga keuangan yang mempunyai kegiatan memberikan pinjaman kepada setiap masyarakat yang ada di perdesaan, tujuan di dalam memberikan dana tersebut adalah untuk meningkatkan modal usaha yang mereka jalani agar usaha dapat berkembang secara maksimal, pinjaman modal yang dapat diberikan dengan rentang Rp 5.000.000,- sampai dengan Rp 15.000.000,tergantung kebutuhan usaha yang mereka miliki. Pinjaman tersebut tidak membutuhkan agunan seperti yang dilakukan oleh lembaga keuangan seperti perbankan.

Kabupaten Bintan memiliki potensi di bidang pariwisata, industri, perikanan, pertambangan dan peternakan. Untuk bidang pariwisata yang menjadi unggulan adalah iklim dan kondisi alam yang eksotis sehingga menjadi daya tarik tersendiri bagi wisatawan baik domistik maupun wisatawan asing, seperti lagoi yang memiliki pemandangan laut dan pantainya yang indah. Selain itu pada sector industry kabupaten bintan mempunyai kawasan industri di lobam sebagai salah satu hasil kerjasama ekonomi antara singapura, Malaysia, dan Indonesia. Perikanan berperan penting di kabupaten ini dengan didukung oleh luas wilayah perairan laut $95 \%$. Pada sektor peternakan daerah ini sangat potensial untuk pengembangan peternakan sapi, kambing, itik, dan ayam sebagai pasokan bahan pangan di daerah perkotaan baik tanjungpinang maupun batam. Pada sector pertanian juga menjadi andalan terutama untuk mencukupi pasokan sayur mayur terutama di kedua kota tersebut.

Kabupaten Bintan sangat berpotensi dalam perkembangan bisnis usaha mikro, kecil dan menengah (UKM). Mengingat sering dijadikan tujuan wisata bagi wisatawan lokal maupun mancanegara begitu juga dengan even-even bertaraf internasional yang sudah menjadi kalender tahunan di kabupaten ini, namun demikian pembinaan terhadap UKM masih sangat terbatas karena anggaran yang masih minim, sehingga program pengembangan dan pembinaan juga membatasi jumlah UKM.

Dalam pengembangan UKM persoalan yang paling sering muncul adalah masalah permodalan dan pemasaran. Permodalan dasar utamanya yaitu karena sistem akuntansi yang belum diterapkan, dikarenakan UKM banyak mengalami kendala dalam pembuatannya, yaitu minimnya ilmu yang dimiliki tentang sistem akuntansi dan hal itu merupakan kendala sebagian besar yang dihadapi oleh beberapa UKM, dengan kata lain, tidak mengerti harus bagaimana, apa yang harus dipersiapkan, dan bagaimana menerapkannya, sehingga dalam penulis tertarik untuk mengangkat penelitian ini dengan judul "Penerapan Akuntansi pada Kelompok Usaha Kecil Menengah Eks PNPM di Kabupaten Bintan"

Berdasarkan latar belakang diatas, maka rumusan masalah dalam penelitian ini adalah 1) Apakah kelompok Usaha Ekonomi Masyarakat (UKM) Eks PNPM di Kabupaten Bintan sudah menerapkan praktik akuntansi sesuai dengan kaidah- kaidah akuntansi yang benar, 2) 
Bagaimana pencatatan transaksi keuangan yang dilakukan pada UKM yang menggunakan modal pinjaman dari UPK eks PNPM di Kabupaten Bintan?

\section{LANDASAN TEORI}

\section{Definisi UKM Pada UKM}

Dalam perekonomian Indonesia Usaha Kecil dan Menengah (UKM) merupakan kelompok usaha yang memiliki jumlah paling besar dan terbukti tahan terhadap berbagai macam goncangan krisis ekonomi. Untuk itu diperlukan penguatan kelompok UKM yang melibatkan banyak kelompok.Definisi dan UKM berdasarkan instansi sebagai berikut:

\section{Pasal 6 UU no.20 tahun 2008 tentang UKM}

Usaha mikro adalah suatu usaha yang memiliki kekayaan bersih paling banyak Rp50 juta sampai dengan Rp500 juta dan itu tidak termasuk tanah dan tempat bangunan usaha, serta total penjualan tahunannya paling banyak sekitar Rp300 juta. Usaha kecil adalah suatu usaha yang memiliki kekayaan lebih dari Rp50 juta sampai dengan Rp500 juta tidak termasuk tanah dan tempat bangunan usaha, dan total penjualan tahunannya paling banyak Rp300 sampai dengan Rp2,5 milyar Usaha menengah adalah suatu usaha yang memiliki kekayaan lebih dari Rp500 juta sampai dengan Rp1 milyar tidak termasuk dengan tanah dan tempat bangunan usaha, dan memiliki total penjualan tahunan paling banyak Rp2,5 milyar sampai dengan Rp50 milyar.

\section{Badan Pusat Statistik (BPS)}

Usaha mikro adalah suatu usaha yang mempekerjakan tenaga kerja lebih kecil dari empat orang dan sudah termasuk tenaga kerja yang tidak dibayar.Usaha kecil adalah suatu usaha yang mempekerjakan tenaga kerja 5 - 19 orang. Sedangkan usaha menengah adalah suatu usaha yang mempekerjakan tenaga kerja 20 - 99 orang tenaga kerja.

\section{Bank Indonesia}

Usaha mikro adalah suatu usaha yang dijalankan oleh masyarakat miskin, yang dimiliki oleh keluarga, bersumber daya lokal dan menggunakan teknologi yang sederhana, dan lapangan usaha nya mudah untuk keluar dan masuk. Usaha kecil adalah suatu usaha yang memiliki aset lebih kecil dari Rp200 juta tidak termasuk tanah dan bangunan usaha, omset tahunan lebih kecil dari Rp1 milyar dan dimiliki oleh orang Indonesia, dan harus berbadan hukum tidak boleh tidak. Usaha menengah adalah suatu usaha yang memiliki aset lebih kecil dari Rp5 milyar untuk sektor industri, dan aset lebih kecil dari Rp600 juta tidak termasuk tanah dan bangunan usaha untuk sektor nonindustri, omset pertahun lebih kecil dari Rp3 milyar.

\section{Pengertian Akuntansi}

Menurut Kieso (2002), akuntansi didefinisikan secara tepat dengan menjelaskan tiga karakteristik penting dari akuntansi: (1) pengidentifikasian, pengukuran, dan pengkomunikasian informasi keuangan tentang (2) entitas ekonomi kepada (3) pemakai yang berkepentingan. Secara umum, akuntansi dapat didefinisikan sebagai sistem informasi yang menghasilkan laporan kepada pihak-pihak yang berkepentingan mengenai aktivitas ekonomi dan kondisi perusahaan. (Warren, 2006). 
Menurut Carl S. Warren, James M. Reeve dan Philip E. Fees (2006) Akuntansi merupakan sistem informasi yang menghasilkan laporan kepada pihak-pihak yang berkepentingan mengenai aktivitas ekonomi dan kondisi perusahaan. Laporan keuangan menurut Ikatan Akuntan Indonesia (2000) dalam Standar Akuntansi Keuangan terdiri dari 5 (lima) yaitu: neraca, laporan laba-rugi, laporan perubahan modal, laporan arus kas dan catatan atas laporan keuangan. Laporan-laporan tersebut mempunyai fungsi masing-masing yang berguna untuk memberikan informasi mengenai posisi bisnis suatu usaha.

Laporan Laba Rugi adalah suatu ikhtisar pendapatan dan beban selama periode tertentu, misal sebulan atau setahun. Laporan ini melaporkan tentang pendapatan dan beban selama periode waktu tertentu berdasarkan konsep penandingan atau matching concept yaitu dengan membandingkan beban dengan pendapatan yang dihasilkan selama periode terjadinya beban tersebut. Laporan ini juga melaporkan kelebihan pendapatan terhadap beban-beban yang disebut dengan keuntungan bersih atau juga sebaliknya, jika beban lebih besar dari pada pendapatan disebut rugi bersih. (Warren, 2006).

Laporan Perubahan modal suatu ikhtisar mengenai perubahan pada modal pemilik yang telah terjadi selama periode waktu tertentu seperti pada bulanan maupun tahunan. Laporan ini dibuat setelah laporan laba rugi karena laporan laba rugi ikut muncul pada laporan ini. (Warren, 2006).

Neraca merupakan sebuah laporan yang berisi daftar mengenai aset, kewajiban, dan modal pemilik pada tanggal tertentu. Pada umumnya tanggal pada neraca menggunakan hari pada akhir bulan atau akhir tahun. (Warren, 2006).

Laporan Arus Kas adalah laporan yang menggambarkan arus kas masuk dan arus kas keluar atau setara kas. Laporan Arus Kas dapat memberikan informasi yang memungkinkan para pemakai untuk mengevaluasi perubahan dalam Aset bersih perusahaan, struktur keuangan (termasuk likuiditas dan solvabilitas) dan kemampuan untuk mempengaruhi jumlah serta waktu arus kas dalam rangka adaptasi dengan perubahan keadaan dan peluang. Informasi Arus Kas juga berguna untuk menilai kemampuan perusahaan dalam menghasilkan kas dan setara kas dan memungkinkan para pemakai mengembangkan model untuk menilai dan membandingkan nilai sekarang dari arus kas masa depan (future cash flows) dari berbagai perusahaan (Endif, 2009). Dalam metode berbasis kas, pendapatan dilaporkan pada periode dimana kas didapatkan atau diterima.

Akuntansi bermanfaat untuk menghasilkan laporan yang berfungsi sebagai sumber informasi utama yang menjadi dasar dalam pengambilan keputusan bagi pemangku kepentingan atau stake holder (Warren, 2006)..

\section{Akuntansi Berbasis Komputer}

Perkembangan zaman banyak berpengaruh terhadap bidang teknologi, yang dapat dilihat pada awal tahun 1990-an maraknya penggunaan komputer pribadi. Pengguna komputer di Indonesia mulai mengenal program aplikasi akuntansi berbasis sistem operasi DOS (disk operating system).Saat itu program yang paling popular adalah DacEasy Accounting (DEA).DEA merupakan pertama yang dikenal dan diajarkan di beberapa perguruan tinggi maupun lembaga kursus.Sejalan dengan perkembangan teknologi informasi, sistem operasi komputer mulai bergeser ke Windows. Program aplikasi lain mulai dikenal seperti MYOB, Peachtree, Accpacc, 
Simply Accounting, Platinum,Accounting Professional, dan QuickBook yang merupakan produk luar negeri.

Program aplikasi akuntansi buatan Indonesia antara lainAccurate2000, Zahir Accounting, dan Jamparing (Arifin, 2008). Program tersebut pada dasarnya dibuat massal dan siap dioperasikan untuk mengolah data akuntansi untuk perusahaan dagang atau jasa.Jarang sekali program aplikasi akuntansi yang dibuat untuk keperluan perusahaan manufaktur. Prosedur pengoperasian setelah program terpasang dikomputer, yaitu pengguna melakukan pengaturan awal periode akuntansi, menyiapkan nama akun, nama pemasok, nama pelanggan, pencatatan data barang, mengatur akun penghubung dan saldo awal.

\section{Microsoft Excel}

Banyak sekali para pelaku bisnis yang menggunakan Microsoft excel untuk menyelenggarakan sistem akuntansi pada perusahaannya. Penggunaannya sangat mudah dan fleksibel, serta banyak sekali manfaat yang dapat diambil. Apabila dibandingkan dengan cara manual, sistem dengan komputerisasi jelas banyak memberikan keuntungan, disamping efisiensi waktu dan tenaga, mendapatkan kemudahan untuk mengakses data dan sehingga data menjadi akurat.Data-data dari setiap perusahaan pasti berbeda-beda, dengan Microsoft Excel, dapat dengan mudah menyesuaikan dengan kebutuhan.Microsoft excel merupakan salah satu program yang ada dalam Microsoft Office System.

Excel yang dibagi secara real time antara beberapa mesin, dan juga dapat dilihat dan diedit melalui halaman web. Data akuntansi pada Microsoft Excel masih bisa mengikuti siklus akuntansi sebagaiman akuntansi manual, namun tidak persis seperti sama dengan akuntansi manual. Otomatisasi siklus akuntansi dengan Excel berawal dari jurnal transaksi. Dari kejadian tersebut laporan keuangan secara otomatis sudah terisi. Dengan demikian, setiap transaksi secara otomatis akan mempengaruhi neraca atau laporan laba rugi. Proses akuntansi ini tidak lagi memerlukan proses posting, pembuatan neraca lajur, jurnal penyesuaian dan sejenisnya untuk menghasilkan neraca dan laporan laba rugi setelah pajak. Dalam hal ini tidak perlu repot menyusun buku besar karena data historis setiap akun atau rekening sudah secara otomatis terisi melalui jurnal transaksi.

\section{Laporan Keuangan}

Laporan Keuangan adalah sarana komunikasi dari sebuah perusahaan kepada pihakpihak yang berkepentingan.Dapat disimpulkan laporan keuangan adalah laporan akuntansi utama yang mengkomunikasikan informasi keuangan kepada pihak-pihak yang berkepentingan, sebagai bahan pertimbangan dalam pengambilan keputusan ekonomi.Laporan keuangan perusahaan didasarkan pada aturan-aturan akuntansi dan harus memberikan informasi historis, kuantitatif dasar yang merupakan sekumpulan input penting yang digunakan dalam menghitung nilai-nilai ekonomi. 


\section{Harga Pokok Penjualan}

Harga Pokok Penjualan adalah biaya yang muncul dari barang yang diproduksi dan dijual dalam kegiatan bisnis. Harga Pokok Penjualan pada umumnya ada pada perusahaan dagang. Karena kegiatan utama perusahaan dagang adalah memperjual belikan barang dagangan. Secara sederhana, harga pokok penjualan (Cost of Goods Sold) didefinisikan sebagai harga barang yang dijual atau harga barang yang terjual atau harga beli barang dagang. Selain dapat didefinisikan sebagai harga barang yang dijual, harga pokok penjualan juga dapat diartikan sebagai semua biaya yang muncul dalam proses yang dilalui untuk menghasilkan suatu produk hingga produk tersebut telah siap untuk dijual.

Dari pengertian tersebut, harga pokok penjualan (Cost of Goods Sold) dapat diartikan sebagai harga atau biaya yang harus dikeluarkan baik yang bersifat langsung atau tidak langsung hingga barang tersebut siap untuk dijual.

Harga pokok penjualan dihitung berdasarkan dari harga pokok rata-rata tanpa memperdulikan jumlah barang dagang, hanya memperhatikan berapa kali pembelian barang dagang yang dilakukan. Metode atau cara ini memang sangat sederhana namun tidak dapat menghasilkan harga pokok penjualan yang akurat karena tidak dapat mewakili harga dari seluruh persediaan.

\section{METODE PENELITIAN}

\section{Objek Penelitian}

Objek penelitian dalam penelitian ini adalah pelaku usaha kecil dan menengah (UKM) yang dalam menjalankan usahanya menggunakan dana guliran dari Eks PNPM yang saat ini dikelola oleh Unit Pelayanan Teknis (UPT) di Kabupaten Bintan Provinsi Kepulauan Riau, dengan menitikberatkan terhadap kegiatan pengelolaan/penerapan akuntansinya, sehingga dapat diketahui sejauh mana para pelaku usaha kecil dan menengah menerapkan kaidah-kaidah akuntansi dalam mengembangkan usahanya.

\section{Data dan Variabel}

Terdapat dua data yang digunakan dalam penelitian ini adalah data primer dan data sekunder, data primer yaitu data yang diperoleh langsung dari responden yang dijadikan sumbernya. Data sekunder (secondary data) merupakan data yang diperoleh dan digunakan sebagai data penunjang. Dalam penelitian ini data didapat dari Dinas Pemberdayaan Masyarakat Kabuparen Bintan, dan Disperindakop, seperti kontribusi UKM terhadap perekonomian Indonesia, peranan UKM terhadap PDB, dan jumlah UKM.

\section{Metode Pengumpulan Data}

Dalam rangka mengumpulkan data-data yang diperlukan pada penelitian ini, penulis melakukan teknik pengumpulan data sebagai berikut:

1) Penelitian Lapangan (Field Research)

Dalam pengumpulan data atau informasi, penulis menggunakan teknik penelitian dengan cara mendatangi UKM-UKM yang bersangkutan secara langsung dengan pihak terkait guna mendapatkan data primer dan informasi yang akurat. Pengumpulan data ini dapat dilakukan dengan cara: 
a. Wawancara, yaitu teknik pengumpulan data dengan cara mengajukan pertanyaan lisan secara langsung.

b. Kuesioner, teknik pengumpulan data dengan cara mengajukan serangkaian pertanyaan tertulis mengenai hal-hal yang berkaitan dengan masalah yang diteliti kepada para responden.

Populasi dalam penelitian ini adalah UKM sebagai kelompok Usaha Ekonomi Masyarakat (UEM) yang menggunakan dana bergulir Eks PNPM di Kabupaten Bintan sebanyak 780 kelompok usaha dengan pelaku usaha sebanyak 5.460 UKM, Dan untuk mendapatkan sampel yang dapat menggambarkan populasi, maka dalam penentuan sampel penelitian ini digunakan rumus Slovin (dalam Umar, 2004:108) sebagai berikut:

$$
\mathrm{n}=\frac{\mathrm{N}}{1+\mathrm{Ne}^{2}}
$$

Dimana:

$\mathrm{n}$ : ukuran sampel

$\mathrm{N}$ : ukuran populasi

e : persen kelonggaran ketidaktelitian karena kesalahan pengambilan sampel yang masih dapat ditolerir.

Dari jumlah populasi tersebut dengan tingkat kelonggaran 10\%, maka dengan menggunakan rumus di atas diperoleh sampel sebesar:

$$
\mathrm{n}=\frac{5.460}{1+5.460(0.1)^{2}}=98,2=100 \text { Orang }
$$

2) Penelitian Kepustakaan (Library Research), yaitu teknik pengumpulan data untuk penelitian yang didapat dari buku-buku, buku pelengkap, data-data dari jurnal, internet serta sumber lain yang relevan dengan penelitian.

\section{Skala Pengukuran}

Menurut Muslimin (2002:28) Skala pengukuran merupakan seperangkat aturan yangdiperlukan untuk mengkuantitatifkan data dari pengukuran suatu variabel. Dalam pengolahan data hasil kuesioner penulis menggunakan skala Guttman, yaitu untuk jawaban "Ya" diberikan skor satu, sedangkan untuk jawaban "Tidak" diberikan skor nol dengan ketentuan yang dikemukakan oleh Sugiyono (2004:90) mengenai skala Guttman, ketentuannya adalah sebagai berikut:

Keterangan :

$$
\frac{\sum \text { Jawaban "Ya" }}{\sum \text { Jawaban Kuesioner }} \times 100 \%
$$

$0.00-0.25=$ No association or low association (weak association)

$0.25-0.50=$ Moderately low association (moderately weak association)

$0.51-0.75=$ Moderately high association (moderately strong association)

$0.76-1=$ High association (strong association) up to perfect association 
Berdasarkan kriteria tersebut, jika dikaitkan dengan penelitian dapat dijelaskan sebagai berikut:

a. $0 \%-25 \%$, = Pelaku UKM tidak menerapkan akuntansi pada pengelolaan keuangannya

b. $26 \%-50 \%$, = Pelaku UKM kurang menerapkan akuntansi pada pengelolaan keuangan

c. $51 \%-75 \%$, = Pelaku UKM cukup menerapkan akuntansi pada pengelolaan keuangan

d. $76 \%-100 \%$, = Pelaku UKM sangat menerapkan akuntansi pada pengelolaan keuangan

\section{HASIL PEMBAHASAN}

\section{Profil Singkat Objek}

Penelitian ini dilakukan pada 100 kelompok usaha atau Usaha Ekonomi Masyarakat (UEM) yang menggunakan dana operasionalnya dari UPK (Eks PNPM). Sampel ini diambil secara acak yang tersebar di 10 kecamatan yang ada di Kabupaten Bintan. Kabupaten Bintan memiliki pertumbuhan ekonomi diatas 5,3\%. Pertumbuhan pelaku UMKM tentunya mempunyai andil ikut serta berkontribusi. Untuk membangun perekonomian yang lebih maju, jika terdapat $5 \%$ pelaku UKM dari jumlah penduduk kabupaten bintan, berarti akan ada sekitar 7.500 pelaku usaha.

\section{Hasil Penelitian}

UKM di Kabupaten Bintan terbagi menjadi beberapa bentuk usaha, antara lain, home industri kerajinan, perdagangan, pertanian, perikanan dan jasa.dari jumlah tersebut ada 780 kelompok usaha dengan pelaku usaha sebanyak 5.460 orang yang permodalannya menggunakan dana dari PNPM. dengan jumlah dana yang dikelola sekitar Rp 22 milyar yang tersebar di 10 kecamatan di kabupaten bintan dengan sebaran sebagai berikut :

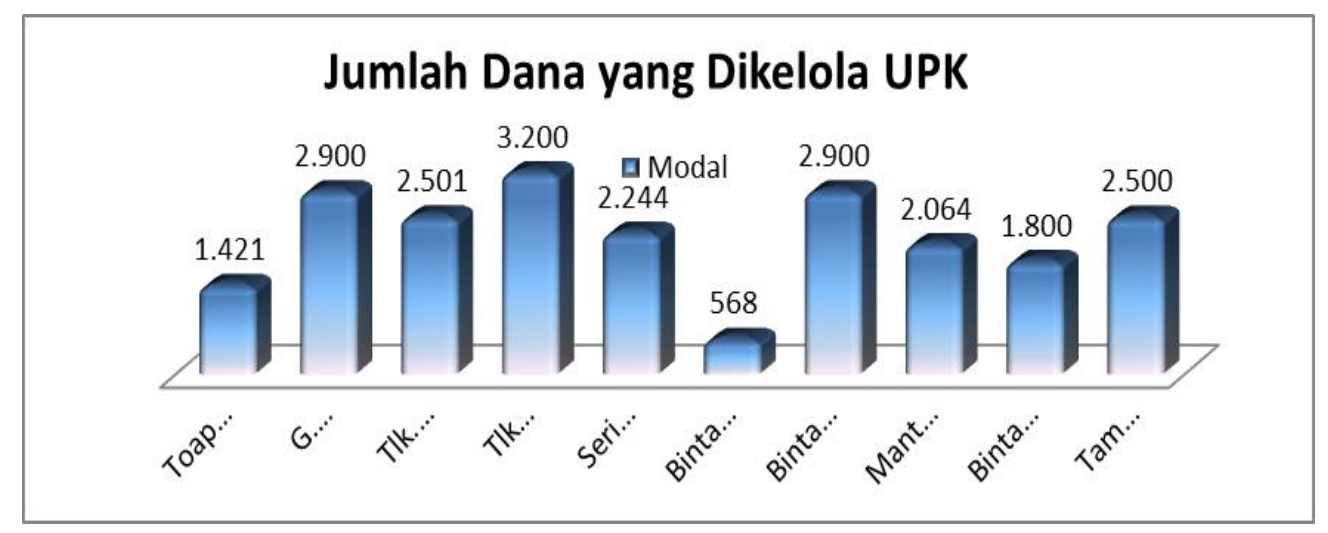

Gambar 1: Jumlah Dana yang Dikelola UPK (Eks PNPM)

Sumber : Data diolah

Jumlah anggota dalam satu kelompok cukup bervariasi dengan jumlah terkecil sebanyak 5 orang yaitu pada kelompok UEM di kecamatan Seri Kuala Lobam dan Kecamatan Bintan Utara, sedangkan jumlah terbanyak dalam satu kelompok adalah di Kecamatan Teluk Sebong sebanyak 10 orang, dan jumlah rata-rata seluruhnya adalah 7 orang dalam satu kelompok.

Dalam setiap kelompok akan ditunjuk satu orang yang dianggap mampu menangani persoalan-persoalan manajerial, seperti mengatur jadwal angsuran, mengecek anggota yang mengalami masalah sehingga gagal bayar dan lain-lain, sehingga faktor pendidikan menjadi 
penting. Dari hasil angket bahwa jenjang pendidikan ketua kelompok yang paling dominan adalah jenjang SMU sebanyak $88 \%$ dan tidak ada lulusan SD, sebagaimana disajikan pada gambar berikut ini :

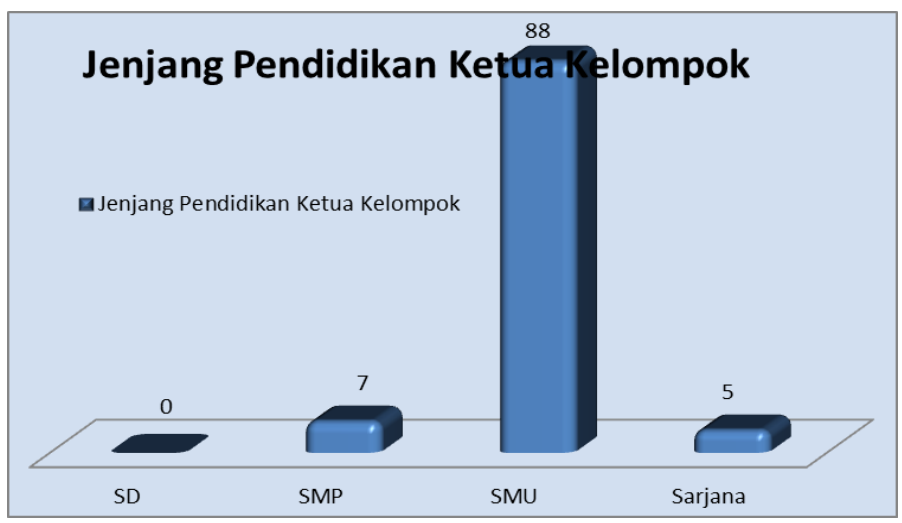

Gambar 2 : Jenjang Pendidikan Ketua Kelompok UEM

Dalam aktifitas UPK kecamatan yang akan mendistribusikan dana sebagai modal setiap kelompok usaha yang mengajukan pinjaman, maka UPK akan memproses proposal pinjaman dana yang diajukan oleh masing-masing kelompok . jumlah dana yang diajukan adalah merupakan akumulasi pinjaman dari seluruh anggota, dan tidak ada dana operasional untuk kelompok karena kelompok tidak melaksanakan fungsi administrasi selain hanya mencatat pinjaman dan angsuran anggota dimana persyaratan peminjaman adalah : menjadi anggota kelompok dan sudah memiliki usaha. Adapun jumlah kelompok UEM yang dilayani UPK adalah sebanyak 780 kelompok dengan jumlah peminjaman yang paling banyak ada pada bidang perdagangan dan jasa sebanyak 337 kelompok atau $43,21 \%$ dan yang paling kecil ada pada bidang peternakan yaitu 61 kelompok atau $7,82 \%$.

Hasil penelitian menemukan bahwa hampir sebagian besar Kelompok Usaha Ekonomi Masyarakat di Kabupaten Bintan belum memahami dan menerapkan akuntansi dalam aktifitas bisnis mereka. Berikut hasil jawaban yang telah didapat dari responden yaitu :

Tabel 3 : Persamaan Dasar Akuntansi

\begin{tabular}{c|c|c}
\hline Memahami Persamaan Akuntansi & Frekuensi & Persentase \\
\hline Ya & 41 & $41 \%$ \\
Tidak & 59 & $59 \%$ \\
\hline
\end{tabular}

sumber : Data Diolah Sendiri

Dari pertanyaan yang telah diberikan kepada responden yaitu mengenai apakah UKM memahami persamaan dasar akuntansi atau persamaan akuntansi, maka jawaban responden melalui kuesioner yang telah diberikan kepada 100 UKM diketahui 41 UKM yang mengetahui persamaan dasar akuntansi dasar dan sebanyak 59 UKM masih belum mengetahui apa itu persamaan dasar akuntansi. Sehingga dapat dikatakan ada $41 \%$ yang mengetahui persamaan dasar akuntansi dan $59 \%$ yang tidak mengetahui persamaan persamaan dasar akuntansi dalam menjalankan usahanya

Tabel 4: Aset Entitas 


\begin{tabular}{c|c|c}
\hline Memisahkan aset usaha dgn aset sendiri & Frekuensi & Persentase \\
\hline Ya & 43 & $43 \%$ \\
Tidak & 57 & $57 \%$ \\
\hline
\end{tabular}

sumber : Data Diolah Sendiri

Pertanyaan apakah UKM melakukan pemisahan harta antara harta usaha dan harta milik pribadi sehingga tidak bercampur aduk. Maka jawaban responden melalui kuesioner, dari 100 responden memberikan jawaban bahwa sebanyak $43 \%$ atau 43 UKM menjawab Ya, berarti sudah memisahkan asset sendiri dengan asset usaha, dan sisanya $57 \%$ tidak memisahkan antara assert sendiri dan asset untuk usahanya.

Tabel 5 : Membuat Bukti Transaksi

\begin{tabular}{c|c|c}
\hline Membuat Bukti Transaksi & Frekuensi & Persentase \\
\hline Ya & 59 & $59 \%$ \\
Tidak & 41 & $41 \%$ \\
\hline
\end{tabular}

sumber : Data Diolah Sendiri

Untuk pertanyaan apakah UKM membuat bukti transaksi dalam menjalankan aktifitas usahanya. Maka jawaban responden yang sudah membuat bukti transaksi, yaitu sebesar $59 \%$ atau sebanyak 59 UKM yang membuat bukti transaksi dan sisanya sebesar $41 \%$ atau 41 UKM tidak membuat bukti transaksi dalam menjalankan aktifitas usaha mereka.

Tabel 6: Mencatat Seluruh Transaksi

\begin{tabular}{c|c|c}
\hline Mencatat Seluruh Transaksi & Frekuensi & Persentase \\
\hline Ya & 67 & $67 \%$ \\
Tidak & 33 & $33 \%$ \\
\hline
\end{tabular}

sumber : Data Diolah Sendiri

Pertanyaan apakah UKM melakukan pencatatan atas seluruh transaksi dalam kegiatan usahanya. Maka jawaban responden menyatakan bahwa sebesar $67 \%$ atau 67 UKM yang mencatat seluruh transaksi dan sisanya sebesar 33\% atau 33 UKM tidak melakukan pencatatan atas transaksi yang terjadi dalam menjalankan usahanya.

Tabel 7 : Mencatat Pengambilan Pribadi

\begin{tabular}{c|c|c}
\hline Mencatat Pengambilan Pribadi & Frekuensi & Persentase \\
\hline Ya & 36 & $36 \%$ \\
Tidak & 64 & $64 \%$ \\
\hline
\end{tabular}

sumber : Data Diolah Sendiri

Pertanyaan apakah UKM melakukan pencatatan apabila terjadi pengambilan pribadi. Maka jawaban responden menyatakan bahwa sebesar 36\% atau 36 UKM yang mencatat apabila terjadi pengambilan untuk kepentingan pribadi dan sisanya sebesar $64 \%$ atau 64 UKM tidak melakukan pencatatan atas transaksi pengambilan pribadi (prive) dalam aktifitas usahanya. 
Tabel 8: Pembebanan Aset Tetap

\begin{tabular}{c|c|c}
\hline Membebankan Aset Tetap & Frekuensi & Persentase \\
\hline Ya & 28 & $28 \%$ \\
Tidak & 72 & $72 \%$ \\
\hline
\end{tabular}

sumber : Data Diolah Sendiri

Pertanyaan apakah UKM melakukan pencatatan untuk membebankan asset tetap (mencatat penyusutan asset tetap) dalam kegiatan usahanya. Maka jawaban responden menyatakan bahwa sebesar $28 \%$ atau 28 UKM yang membebankan asset tetap dan sisanya sebesar $72 \%$ atau 72 UKM tidak melakukan pembebanan terhadap asset tetapnya dalam aktifitas usahanya.

Tabel 9: Mencatat Semua Unsur dalam HPP

\begin{tabular}{c|c|c}
\hline Mencatat semua unsur HPP & Frekuensi & Persentase \\
\hline Ya & 61 & $61 \%$ \\
Tidak & 39 & $39 \%$ \\
\hline
\end{tabular}

sumber : Data Diolah Sendiri

Pertanyaan apakah UKM mencatat atas semua unsur dalam Harga Pokok Penjualan (HPP). Maka jawaban responden menyatakan bahwa sebesar $61 \%$ atau 61 UKM yang mencatat semua unsur dalam perhitungan harga pokok penjualan dan sisanya sebesar $39 \%$ atau 39 UKM tidak mencatat atas semua unsur dalam Harga Pokok Penjualan (HPP) dalam aktifitas usahanya

Tabel 10: Menghitung HPP Per unit

\begin{tabular}{c|c|c}
\hline Menghitung HPP Per unit & Frekuensi & Persentase \\
\hline Ya & 64 & $64 \%$ \\
Tidak & 36 & $36 \%$ \\
\hline
\end{tabular}

sumber : Data Diolah Sendiri

Pertanyaan apakah UKM menghitung Harga Pokok Penjualan (HPP). Maka jawaban responden menyatakan bahwa sebesar $64 \%$ atau 64 UKM yang mencatat semua unsur dalam perhitungan harga pokok penjualan dan sisanya sebesar $36 \%$ atau 36 UKM tidak menghitung Harga Pokok Penjualan (HPP) dalam aktifitas usahanya.

Tabel 11: Menentukan Penjualan Paling Minimal

\begin{tabular}{c|c|c}
\hline Menentukan Penjualan Minimal & Frekuensi & Persentase \\
\hline Ya & 45 & $45 \%$ \\
Tidak & 55 & $55 \%$ \\
\hline
\end{tabular}

sumber : Data Diolah Sendiri

Untuk pertanyaan apakah UKM dapat menentukan penjualan paling minimal. Maka jawaban responden menyatakan bahwa sebesar $45 \%$ atau 45 UKM yang menentukan penjualan paling 
minimal dan sisanya sebesar $55 \%$ atau 55 UKM tidak menentukan penjualan paling minimal dalam aktifitas usahanya

Tabel 12: Menyusun Laporan Keuangan

\begin{tabular}{c|c|c}
\hline Menyusun Laporan Keuangan & Frekuensi & Persentase \\
\hline Ya & 51 & $51 \%$ \\
Tidak & 49 & $49 \%$ \\
\hline
\end{tabular}

sumber : Data Diolah Sendiri

Pertanyaan apakah UKM dapat menyusun laporan keuangan setiap tahunnya. Maka jawaban responden menyatakan bahwa sebesar $51 \%$ atau 51 UKM yang menyusun laporan keuangan setiap tahunnya.dan sisanya sebesar $49 \%$ atau 49 UKM tidak menyusun laporan keuangan setiap tahunnya.dalam aktifitas usahanya.

Hasil dari jawaban responden dalam menerapkan sistem akuntansi menunjukan penerapan sistem akuntansi oleh usaha kecil dan menengah yang bergerak dalam berbagai bidang usaha Kabupaten Bintan, diketahui bahwa dari total responden yaitu sebanyak 100 responden pelaku usaha kecil dan menengah menunjukkan bahwa penerapan sistem akuntansi oleh usaha kecil dan menengah masih kurang. Berikut adalah skor perolehan penerapan sistem akuntansi oleh usaha kecil dan menengah yang bergerak dalam berbagai bidang usaha Kabupaten Bintan

Tabel 13: Distribusi Skor Penerapan Akuntansi

\begin{tabular}{ccccc}
\hline \multirow{2}{*}{ No. } & \multicolumn{2}{c}{ Jawaban } & \multirow{2}{*}{ Skor } & Rata - rata \\
\cline { 2 - 3 } & Ya & Tidak & & $\mathbf{0 . 4 1 0}$ \\
\hline \hline 1 & 41 & 59 & 41 & $\mathbf{0 . 4 3 0}$ \\
3 & 43 & 57 & 43 & $\mathbf{0 . 5 9 0}$ \\
4 & 59 & 41 & 59 & $\mathbf{0 . 6 7 0}$ \\
5 & 67 & 33 & 67 & $\mathbf{0 . 3 6 0}$ \\
6 & 36 & 64 & 36 & $\mathbf{0 . 2 8 0}$ \\
7 & 28 & 72 & 28 & $\mathbf{0 . 6 1 0}$ \\
8 & 61 & 39 & 61 & $\mathbf{0 . 6 4 0}$ \\
9 & 64 & 36 & 64 & $\mathbf{0 . 4 5 0}$ \\
10 & 45 & 55 & 45 & $\mathbf{0 . 5 1 0}$ \\
\hline & 51 & 49 & 51 & $\mathbf{0 . 4 9 5}$ \\
\hline
\end{tabular}

Sumber : data diolah

Dari tabel 13 di atas dengan memberikan skor 1 (satu) untuk jawaban ya dan 0 (nol) untuk jawaban tidak, maka dapat rata-rata skor tertimbang adalah 0,495 di mana apabila mengacu pada skala Guttman, maka skala tersebut berada pada range $0.26-0.50$ yaitu Moderately low association (moderately strong association). Dengan demikian dapat disimpulkan bahwa dari keterangan angka yang menunjukkan bahwa penerapan akuntansi pada Usaha Kecil dan Menengah (UKM) di Kabupaten Bintan bagi kelompok Usaha Ekonomi masyarakat (UEM) Eks PNPM masih tergolong rendah sampai dengan sedang, yaitu $49 \%$. 


\section{KESIMPULAN DAN REKOMENDASI KEBIJAKAN}

\section{Kesimpulan}

1) Hasil penelitian menunjukkan bahwa kelompok usaha pada UKM di Kabupaten Bintan masih jauh dari kaidah penerapan akuntansi pada aktivitas usahanya. Dari hasil skor tertimbang sebesar 0.49 (Moderately low association (moderately weak association) pada skala Guttman diketahui bahwa penerapan akuntansi di UKM kabupaten Bintan masih kurang.

2) Minimnya penerapan pencatatan akuntansi yang sesuai dengan konsep dan siklus akuntansi yang berlaku umum di Indonesia disebabkan karena kurangnya pengetahuan para pelaku usaha ini akan pentingnya pencatatan akuntansi secara baik dan benar. Selain itu faktor pendidikan juga memberikan pengaruh dalam penerapan pencatatan akuntansinya.

3) Selain faktor pendidikan, penerapan pencatatan akuntansi juga disebabkan oleh kurangnya keinginan dari pelaku usaha ini untuk melakukan pencatatan/pembukuan untuk usahannya, dikarenakan cukup merepotkan untuk mencatat setiap transaksi keuangan mereka. Dengan kata lain pelaku UKM tidak memiliki motivasi yang kuat atau berkeinginan untuk menjadi lebih baik di masa yang akan datang.

\section{Rekomendasi}

Penerapan akuntansi pada kelompok usaha kecil menengah Eks PNPM di kabupaten bintan adalah menjadi tanggungjawab semua pihak, terutama pemerintah daerah dalam upaya pembinaan kepada seluruh pelaku usaha yang ada di kabupaten bintan, baik dari sisi pengelolaan manajemen perusahaan, mulai dari perencanaan produk, pemasaran produk, sampai dengan pelaporan keuangannya. Hal ini dapat dilakukan melalui bekerja sama dengan berbagai pihak terutama perguruan tinggi yang ada di Provinsi Kepulauan Riau. Bahwa sudah seharusnya pemerintah daerah membuka peluang untuk menjamin pemasaran produk-produk yang dihasilkan oleh UKM, karena pemerintah mempunyai linked yang luas, apalagi kepri berada di daerah perbatasan sehingga kerjasama ekspor akan lebih berpeluang

\section{DAFTAR PUSTAKA}

Bungin, Burhan, 2003, Analisis Data Penelitian Kualitatif, Jakarta: Raja Grafindo Persada

Endif, 2009, "Penerapan Akuntansi untuk UKM", http://www.penerapan akuntansi untukukm.com. diakses Tanggal 29 Mei 2010.

Ihalauw, John J.O.I. 2000. Bangunan Teori. Fakultas Ekonomi Universitas Kristen Satya Wacana, Salatiga.

Ikatan Akuntan Indonesia, 2014, Standar Akuntansi Keuangan, Jakarta, Salemba Empat

Raja, Oscar, Ferdy Jalu, dan Vincent D'ral, 2010. Kiat Sukses Mendirikan dan Mengelola UKM. Jakarta: Lpress

Supramono, S. 2001. Metode Penelitian. Jakarta : Erlangga

Supranto, Johanes. 2009. Statistik Teori dan Aplikasi. Jakarta: Erlangga

Warren, Carl S., James Reeve dan Philip E. Fees, 2006, Pengantar Akuntansi, Edisi Dua Puluh Satu, Jakarta: Salemba Empat

Warsono, Sony, Arif Darmawan, dan M.Arsyadi Ridha, 2010. Akuntansi UKM Ternyata Mudah Dipahami dan Dipraktikkan. Asgard Chapter Yogyakarta. 
Amanah, sari.2011.Analisis Penerapan Pencatatan Akuntansi Pada Usaha Kecil dan Menegah Binaan Dinas Koperasiumkm Perindustrian dan Perdagangan Kabupaten Lima Puluh Kota.Jurnal.Fakultas Ekonomi. Universitas Muhammadiyah Sumatera Barat

Baridwan, Zaki, 2014, Intermediate Accounting, Edisi 8, Penerbit BPFE UGM,Yogyakarta..

Kieso, Donald. E, Weygandt, Jerry. J, Warfield, Terry. D, 2007, Intermediate Accounting, Jilid1, Edisi Revisi, Alih Bahasa Herman Wibowo, Penerbit Binapura Aksara, Jakarta.

Kurniawati, Tri Fredia. 2011. Makna Penerapan Pencatatan Keuangan Bagi Pelaku Usaha Kecil Menengah (Ukm).Skripsi.Fakultas Ekonomi.Universitas Pembangunan Nasional.

Niswonger , C. Rollin, Carl S. Warren, James M. Reeve, Philip E.Fess, 2003, Prinsip-Prinsip Akuntansi, Penerjemah Alfonsus Sirait, Edisi Ke-19, Jilid 1, Penerbit Erlangga, Jakarta

Singarimbun, Masri dan Effendi, Sovian, Metodologi Penelitian Survey, LP3ES, Jakarta, 2015

Skausen, Stice, Stice. Intermediate Accounting, Edisi I, Salemba Empat, Jakarta, 2004.

Smith, M. Jay And Fred Skousen, 2002, Akuntansi Intermediate Volume Konprehensif, Edisi Ke9, Jilid I, Terjemahan Nugroho Widjajanto, Penerbit Erlangga, Jakarta.

Soemarso, S. R, 2005, Akuntansi Suatu Pengantar, Edisi Kelima, Buku I, Penerbit Rineka Cipta, Jakarta.

Srikandi, Cut dan Aris Budi Setyawan.2004.Analisis Penerapan Siklus Akuntansi pada Usaha Kecil Dan Menengah di Daerah Istimewa Yogyakarta. STIE Megar kencana

Warren, Carl S, James M. Reeve, Philip E. Fess, 2008, Pengantar Akuntansi, Bukusatu-Edisi 21, Salemba Empat, Jakarta.

Weygant, Jerry J, Donald E. Keiso Dan Paul D. Kimmel, 2007, Pengantar Akuntansi, Penerbit Salemba Empat, Jakarta. 